\title{
MANAJEMEN PEMBELAJARAN PENDIDIKAN ANAK USIA DINI ${ }^{1}$ Eti Hadiati ${ }^{2}$ Fidrayani
}

\author{
${ }^{1}$ Universitas Islam Negeri Raden Intan Lampung, Bandar Lampung,Indonesia \\ "Email: etihadiati@ radenintan.ac.id
}

\begin{abstract}
Abstrak
Penelitian ini bertujuan untuk mengetahui bagaimana manajemen pembelajaran pendidikan anak usia dini (PAUD) se-RA kota Bandar Lampung. Metode penelitian ini adalah deskriptif kualitatif. pengumpulan data dengan menggunakan teknik wawancara, dokumentasi, dan observasi dengan menggunakan Model yang berupa analisis data yang digunakan yaitu analisis data interaktif (interactive) atau analisis data mengalir (Flow Model Analisis); yakni model analisis data yang terdiri dari pengumpulan data, reduksi Data, display data, pengambilan kesimpulan dan verifikasi. Teknik trianggulasi data digunakan untuk menguji keabsaan data yang telah dikumpulkan. Hasil penelitian mendiskripsikan bahwa pelaksanaan pembelajaran di sebagian besar RA Se-Kota Bandar Lampung dalam merealisasikan perencanaan pembelajaran dimulai menyusun program tahunan (PROTA) yang berisi kegiatan-kegiatan di RA dari awal tahun ajaran sampai akhir, dilanjutkan dengan penyusunan program semester (PROMES/PROSEM), RKM dan RKH. Dengan menggunakan langkah-langkah dalam pembelajaran dengan perencanaan yang telah disusun yaitu dimulai dengan kegiatan pendahuluan atau kegiatan awal yang ada dalam $\mathrm{RKH} / \mathrm{RPPH}$.
\end{abstract}

Kata Kunci: Manajemen; Pembelajaran; RA; PAUD.

\begin{abstract}
This study aims to find out how the management of early childhood education (PAUD) learning in $R A$ Bandar Lampung city. This research method is qualitative descriptive. data collection using interview techniques, documentation, and observation Data analysis model used is flow data analysis (Flow Model Analysis) or interactive data analysis; that is a data analysis model consisting of data collection, data reduction, data display, conclusion and verification. After the data has been collected, the validity is tested with data triangulation techniques. The results of the study describe that the implementation of learning in most RA throughout the city of Bandar Lampung in realizing learning planning starts compiling an annual program (PROTA) which contains activities in RA from the beginning of the school year to the end, followed by semester programming (PROMES / PROSEM), RKM and RKH. The plan that has been prepared has been implemented in accordance with the steps in learning, starting with preliminary activities or initial activities that are in the RKH / RPPH.
\end{abstract}

Keywords: Management; Learning; RA; PAUD 


\section{PENDAHULUAN}

Saat ini pendidikan parasyarat sebelum masuk kejenjang Sekolah Dasar (SD) seperti PAUD sangat dianjurkan dan ada dikebijakan sistem pendidikan Indonesia (Ita, 2018). Menurut Binet-Simon (1908-1991) dan Gardner (1998) di dalam penelitianya yang terfokus pada perkembangan otak anak menunjukkan perkembangan otak manusia mengalami perkembang yang sangat pesat pada usia tersebut, yaitu mencapai $80 \%$, menurutnya saat anak dilahirkan didunia sudah mencapai perkembangan otaknya sebanyak 25\%, hinggaanak berusia 4 tahun perkembangannya mencapai $50 \%$ dan sampai usia 8 tahun sampai $80 \%$; selanjutnya berkembang mencapai usia 18 tahun (Mulya, 2014). Hal yang menunjukkan bahwa PAUD sangat dibutuhkan sebagai pendidikan sebelum memasuki jenjang Sekolah Dasar (SD). Karena anak usia dini sebagai dasar penentu untuk perkembangan selanjutnya (Mursid, 2015) dan merupakan masa kritis bagi pembentuk karakter (Suharni, 2019).

Lembaga PAUD ialah suatu pemberian layanan pendidikan dengan memberikan pengembangan serta memberikan pengasuhan bagi anak lahir sampai enam tahun dan atau enam tahun sampai dengan delapan tahun, baik yang diselenggarakan oleh instansi pemerintah maupun dengan non pemerintah" (Nurani S, 2013). Sebagian lembaga PAUD (RA dan TK) dalam mendirikan PAUD tidak memperhatikan standar-standar nasional yang sesuai dengan aturan. Seharusnya lembaga PAUD harus menciptakan kualitas guru yang berkompeten dengan memberikan lembaga pendidikan yang bermutu. Oleh karena itu semuah itu tidak terlepas dari adanya manajemen pembelajaran PAUD yang benar.

Manajemen pembelajaran merupakan suatu pengaturan proses belajar mengajar agar terciptanya proses belajar mengajar yang efektif dan efisien, dapat terciptanya proses belajar mengajar yang efektif dan efesien suatu lembaga harus memiliki guru yang memenuhi standar-standar yang sesuai dengan kualifikasi akademik dan berkompeten dibidangnya agar terciptanya kinerja guru yang bermutu. (Bafadal, 2006; Barnawi \& M. Arifin, 2012). Mengingat para guru PAUD akan berhadapan langsung dengan peserta didik yang masih usia dini maka dituntut untuk memiliki kompetensikompetensi tersebut diantaranya kompetensi profesional, kompetensi paedagogik, kompetensi kepribadian dan kompetensi sosial. Guru juga harus menggunakan 
pembelajaran yang bervariasi dan menarik (Kariyana \& Sonn, 2012; Suherman et al., 2018).

Penelitian sebelumnya manajemen pembelajaran anak usia dini pernah dilakukan namun hanya terfokus pada satu sekolah saja seperti di TK Rutosoro Kecamatan Golewa Kabupaten Ngada Flores Nusa Tenggara Timur (Ita, 2018) dan PAUD Bintang Rabbani Pekanbaru (Suharni, 2019). Manajemen pembelajaran PAUD yang dimaksud menyusun program tahunan (PROTA) yang berisi kegiatan-kegiatan di RA dari awal tahun ajaran sampai akhir, dilanjutkan dengan penyusunan program semester (PROMES/PROSEM), rencana kegiatan mingguan (RKM) dan rencana kegiatan harian $(\mathrm{RKH})$.

Keadaan lapangan di lembaga PAUD (RA dan TK) belum mampu mengimplementasikan manajemen pembelajaran PAUD yang seharusnya. Berdasarkan data yang diperoleh dari Ikatan Guru RA (IGRA) Kota Bandar Lampung bahwa sampai dengan sekarang RA yang ada di Kota Bandar Lampung yang terdaftar sebanyak 26 lembaga yang dikelola, dengan jumlah tenaga kependidikan 146 orang. Lembaga Pendidikan RA sayangnya jumlahnya tidak sesuai dengan kondisi pendidik maupun tenaga kependidikannya yang memang berkompeten dibidangnya. Oleh karena itu, kualifikasi pendidikan guru RA di Kota Bandar Lampung banyak yang belum memenuhi standar pendidik yang telah ditetapkan oleh pemerintah termaktub pada Peraturan Menteri Pendidikan Nasional Nomor 137 Tahun 2014 tentang Standar Pendidik dan Tenaga Kependidikan. Data yang diperoleh RA terakreditasi A hanya 1 dari 26 RA selain itu hanya bernilai B dan masih banyak yang belum akreditasi. Hal ini disebbakan kurangnya manajemen di dalam lembaga PAUD yang meliputi perencanaan semester, Rencana Kegiatan Mingguan (RKM) dan Rencana Kegaitan Harian (RKH).

Perbedaan dengan penelitian sebelumnya, penelitian tidak hanya terfokus pada saru lembaga PAUD saja namun penenlitian mencakup daerah yang lebih luas yaitu PAUD atau RA se kota Bandar Lampung.

Dalam kondisi sebagaimana diuraikan, dibutuhkan penelitian yang berjudul manajemen pembelajaran pendidikan anak usia dini se-RA Kota Bandar Lampung. Penelitian ini penting dilakukan karena untuk belum pernah diadakan penelitian 
mengenai manajemen pembelajaran pendidikan anak usia dini se - RA kota Bandar Lampung.

\section{METODE PENELITIAN}

Jenis penelitian ini adalah penelitian deskriptif kualitatif. Subjek dalam penelitian ini ialah semua yang terlibat dalam pelaksanaan pembelajaran di se-RA Kota Bandar Lampung, baik peserta didik, tenaga kependidikan juga yang lainya, yang penulis anggap mampu untuk dijadikan sebagai informan untuk memperoleh data yang penulis harapkan. Sedangkan obyek penelitian ini yaitu berkisar tentang bagaimana manajemen pembelajaran Pendididikan Anak Usia Dini (PAUD) se-RA Kota Bandar Lampung. Penelitian pengumpulan data dengan menggunakan teknik wawancara, dokumentasi, dan observasi.

Analisis data mengalir (Flow Model Analisis) atau analisis data interaktif (interactive) yang penulis gunakan adalah analisis data mengalir (Flow Model Analisis) atau analisis data interaktif (interactive) adalah model analisis data dari Miles dan Huberman; yaitu menggunakan sebuah model analisis data yang memiliki berberapa langkah-langkah sebagai berikut; (1) Pengumpulan Data, (2) Reduksi Data, yaitu data yang diterima dilakukan seleksi terhadap data-data yang didapat, lalu merangkum dan memfokuskan kepada persoalan. (3) Display Data, mensistematisasi data secara jelas dengan membuat bentuk matriks dan grafis jika diperlukaan saat penelitian dan (4) Pengambilan Kesimpulan dan Verifikasi (Milles \& Huberman, 1992) teknik triangulasi data digunakan untuk menguji keabsaan data yang telah dikumpulkan.

Dengan menggunakan metode penelitian kualitatif peneliti dapat memperoleh data dilapangan dengan cara pengumpulan data dari pengalaman empiris yang ada dilapangan. Menurut Bogdan dan Taylor yang yang mengatakan deskriptif kualitatif adalah sebuah penelitian prosedur penelitian yang menghasilkan data deskriptif berupa kata-kata tertulis atau lisan dari orang-orang dan prilaku yang dapat diamati. ${ }^{1}$

Jenis pendekatan ini adalah pendekatan deskriptif kualitatif yaitu penelitian dengan maksud melakukan penyelidikan dengan menggambarkan/melukiskan keadaan

${ }^{1}$ Lexy J. Moleong, Metodologi Penelitian Kualitatif, (Bandung: Remaja Rosdakarya, 1999), hal. 3 
objek dan subjek berdasarkan fakta-fakta yang ada bahwa penelitian ini lebih menekankan pada proses dari pada hasil. Oleh karena itu penulis lebih memfokuskan pada manajemen pembelajaran pendidikan anak usia dini (PAUD) se RA Kota Bandar Lampung, . Sehingga kondisi dilapangan menggambarkan focus penelitian yang akan diteliti.

\section{Teknik Pengumpulan Data}

Pendekatan kualitatif menggunakan teknik pengumpul data dalah sebagai intrumen awal dalam proses pengumpulan data dalam penelitian. Peneliti sebagai intrumen pertama, kkarena seorang peneliti yang secara langsung mengadakan sebuah penelitian ke lapangan untuk melakukan wawancara kepada informen dengan melakukan interaksi, melakukan sebuah pengamatan (observasi) sebagai pengumpulan data dari berbagai sumber data kemudian dikumpulkan dengan teknik wawancara wawancara, dokumentasi, dan observasi. Berikut ini penjelasannya:

a. Wawancara

Wawancara adalah interaksi antara dua pihak untuk memperoleh sebuah informasi yang dilakukan secara langsung untuk memperoleh informasi berupa suatu keadaan yang ada di tempat yang diteliti dengan menetapkan dengan satu tujuan. ${ }^{2}$ Wawancara dapat dilakukan secara langsung secara mendalam terhadap sumber manusia dan subyek utama dalam penelitian ini adalah kepala RA sebagai pelaku utama (top manajer) dalam kegiatan manajemen di RA, serta para guru yang mengajar sebagai unsur yang menerima berbagai kebijakan manajerial. Penerapan wawancara dapat berlangsung terarah tidak kaku dan dapat terbimbing serta lugas untuk menggali sebuah informasi yang benar-benar dibutuhkan dan berkaitan dengan materi penelitian.

b. Observasi

Metode Observasi adalah sebuah informasi yang dapat diamati dalam suatu objek penelitian untuk mendapatkan informasi secara langsung. Adanya sebuah interaksi sosial secara langsung antara peneliti dengan subjek yang diamati oleh peneliti, menggunakan metode observasi sangat membutuhkan

\footnotetext{
${ }^{2}$ Ibid, hal.135
} 


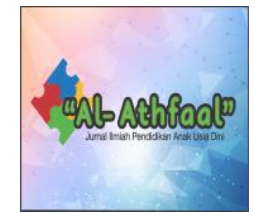

waktu yang relatif lama. ${ }^{3}$ Perekaman dan pencatatan hal-hal seperlunya dalam metode observasi terhadap data-data yang diperlukan. Catatan atau data yang diperoleh dikumpulkan dan disusun secara sistematis tanpa pengaruh dari siapapun.

Metode observasi lebih ditujukan kepada peserta didik dan tenaga pendidik untuk mengetahui tentang bagaimana manajemen pembelajaran PAUD yang dilakukan oleh masing-masing RA.

c. Dokumentasi

Berupa data dari sumber yang peneliti lakukan melalui metode dokumentasi berupa informasi tertulis yang berupa program kerja, notulen rapat, dokumen, surat-surat yang diamati. Menurut Lincoln dan Guba, sebagaimana yang dikutip oleh Moleong, penggunaan dokumentasi dan record sebagai teknik pengumpulan data berdasarkan argumentasi sebagai berikut:

\section{Metode Analisis Data}

Pendekatan penelitian ini dilakukan dari awal penelitian dimulai hingga peneliti menyusun hasil akhir penelitian. Model analisis data yang dipergunakan adalah analisis data interaktif (interactive) analisis data mengalir (Flow Model Analisis) dari Miles dan Huberman; yakni model analisis data yang terdiri dari langkah-langkah sebagai berikut; (1) Pengumpulan Data, (2) Reduksi Data, dalam arti melakukan seleksi terhadap datadata yang diperoleh, merangkum dan memfokuskan kepada persoalan. (3) Display Data, mensistematisasi data secara jelas dalam bentuk yang jelas seperti dengan cara membuat matriks dan grafik jika diperlukan dan (4) Pengambilan Kesimpulan dan Verifikasi. ${ }^{4}$

Kegiatan pengumpulan data,reduksi data, penyajian dan penarik kesimpulan dalam analisis data model interaktif adalah proses siklus yang berlangsung secara terus menerus.

Teknik trianggulasi data digunakan untuk menguji keabsaan data yang telah dikumpulkan. Tujuan triangulasi data adalah untuk mendapatkan informasi dilapangan

${ }^{3}$ Lexi J. Maleong, Op.Cit. hal. 117

${ }^{4}$ Mathew B. Milles dan A. Michael Huberman, Analisis Data Kualitatif, Terj. Cecep Rohindi, (Jakarta: UI Press, 1992). 
benar-benar representatif untuk dijadikan pedoman analisis data untuk mengetahui sejauhmana temuan-temuan mendapatkan informasi yang luas tentang prespektif dalam penelitian.

Tehnik trianggulasi data untuk membanding hasil wawancara, observasi dari banyak sumber untuk satu dua antara ucapan sumber data di depan umum dengan ketika sendirian secara informal, antara hasil wawancara dengan dokumentasi yang diperoleh. Untuk diperoleh peneliti dalam keperluan trianggulasi data juga dilakukan cek-ricek, cros cek, konsultasi dengan kepala RA, para guru dan pengurus komite dan juga bisa tenaga ahli dibidang pendidikan.

\section{A. Data dan Sumber Data}

Data penelitian yang penulis peroleh dari IGRA Kota Bandar Lampung, khususnya mengenai RA yang aktif di Kota Bandar Lampung sebanyak 26 RA yaitu :

Sedangkan sumber data dalam penelitian ini adalah sumber yang berupa manusia, meliputi seluruh anggota personalia yang terlibat dalam proses manajemen pembelajaran pendidikan anak usia dini (PAUD) yaitu para pendidik atau para guru, tenaga kependidikan seperti bagian tata usaha atau administrasi, kepala-kepala RA juga beberapa peserta didik perwakilan dari beberapa RA.

\section{HASIL DAN PEMBAHASAN}

Berdasarkan hasil analisis dari wawancara dari beberapa Sekolah Raudatul Alfhal (RA) maka diperoleh hasil bahwa penyusunan dan persiapan mengajar untuk setiap tahun ajaran baru diawali dengan mempelajari dokumen kurikulumnya terlebih dahulu, yaitu pedoman pengembangan program pembelajaran kemudian menyusun program tahunan (PROTA) yang berisi kegiatan-kegiatan di RA dari awal tahun ajaran sampai akhir, dilanjutkan dengan penyusunan program semester (PROMES/PROSEM) yang dibuat berdasarkan tema-tema pada semester ganjil maupun semester genap dengan adanya alokasi waktu perminggu nya. 


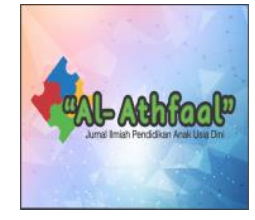

Rencana kegiatan mingguan (RKM) dibuat berdasarkan kegiatan disetiap semester berisi tujuan pembelajaran, strategi, dan kegiatan perminggunya sesuai dengan tema dan alokasi waktu. Sedangkan rencana kegiatan harian (RKH) atau RPPH berisi tanggal, hari, bulan, tahun penggunaan $\mathrm{RKH} / \mathrm{RPPH}$, tema dan sub tema, alokasi waktu, materi pembelajaran, strategi, APE, sumber belajar dilingkungan dan penilaian. Dimana RKH/RPPH ini merupakan panduan tentang perencanaan atau persiapan guru yang akan mengajar setiap tahunnya.

Selanjutnya mengenai model pembelajaran yang diterapkan oleh semua RA berdasarkan hasil dari wawancara dan observasi yaitu sebagian besar semua RA menerapkan model pembelajaran kelompok, klasikal, dan hanya satu RA yang menerapkan model pembelajaran sentra yaitu RA Ar-Rusydah I .

Selanjutnya proses kegiatan pelaksanaan pembelajaran di RA sebagian besar semua RA dalam merealisasikan RKH yang telah disusun tersebut diterapkan sesuai dengan pendahuluan kegiatan awal yaitu terdapat langkah-langkah dalam pembelajaran yaitu ada dalam RKH/RPPH yaitu dimulai dengan baris berbaris, bernyanyi, setelah berdoa dan masuk kelas. Ada juga yang berdoanya setelah di dalam kelas. Dilanjutkan dengan kegiatan inti (tahfiz, materi inti, shalat dhuha) makan, istirahat dan terahir kegiatan penutup yang berisi tentang kegiatan merefleksi pembelajaran, doa dan penutup. Ada juga Dalam kegiatan pendahuluan terdiri dari 15 menit kegiatan didepan kelas "membaca ikrar dan bryn gym.

Pelaksanaan kegiatan kepengawasan di RA tersebut dilakukan oleh penilik atau pengawas yang datang ke RA untuk melakukan pemerikasaan administrasi, dan proses pembelajaran hal itu biasanya dilaksanakan sekali dalam setiap satu semester selama kurang lebh 1 sampai 2 jam. Sedangkan kepala RA juga melakukan pengawasan atau kegiatan supervisi ke kelas-kelas dilakukan ada yang 2 bulan sekali untuk memeriksa administrasi kelas dan memberi arahan kepada para guru. Ada juga yang melakukannya 1 bulan sekali. Tergantung kesempatan yang dimiliki oleh kepala RA masing-masing.

Dalam kegiatan penilaian atau evaluasi untuk peserta didik di semua RA, berdasarkan hasil wawancara dan observasi penulis bahwa setiap harinya guru menggunakan teknik observasi, wawancara, penugasan, dokumentasi dan portofolio. Penilaian juga dilakukan setiap hari, perbulan dan pertahun. Aspek yang dinilai yaitu 
mencakup 5 aspek bidang pengembangan adalah aspek nilai agama\& moral (NAM), bahasa, kognitif, motorik kasar dan halus, dan yang terahir pengembangan seni. kegiatan penilaian atau evaluasi pembelajaran di RA sudah berjalan namun demikian kendala yang hadapi dalam penilaian terlalu banyak indikator yang harus dinilai terutama penilaian mingguan dan bulanan.

Penelitian ini tertuju kepada cakupan daerah yang lebih luas yaitu manajemen se-RA yang ada di Bandar lampung berbeda dengan penelitian-penenlitian yang sudah pernah dilaksanakan sebelumnya hanya terfokus pada satu PAUD atau RA.

\section{KESIMPULAN DAN SARAN}

Kesimpulan dari hasil penelitian disimpulkan manajemen pembelajaran PAUD di se-RA Kota Bandar Lampung bahwa kegiatan pelaksanaan pembelajaran di sebagian besar RA Se-Kota Bandar Lampung dalam merealisasikan perencanaan pembelajaran dimulai menyusun program tahunan (PROTA) yang berisi kegiatan-kegiatan di RA dari awal tahun ajaran sampai akhir, dilanjutkan dengan penyusunan program semester (PROMES/PROSEM), RKM dan RKH. perencanaan yang telah disusun tersebut telah diterapkan sesuai dengan langkah-langkah dalam pembelajaran yaitu dimulai dengan kegiatan pendahuluan atau kegiatan awal yang ada dalam RKH/RPPH.

Peneliti sangat bahwa penulisan ini masih jauh dari kata sempurna, oleh karena itu peneliti mengharapkan kritik dan saran guna bagi pembaca yang sangat membangun dalam penelitian ini. Bagi pihak sekolah hendaknya lebih meningkatkan kinerja guru sehingga manajemen sekolah RA lebih baik. 


\section{DAFTAR PUSTAKA}

Bafadal, I. (2006). Manajemen Perlengkapan Sekolah dan Aplikasinya. Jakarta: Bumi Aksara.

Barnawi, \& M. Arifin. (2012). Etika dan Profesi Kependidikan. yogyakarta: Ar-ruz Media.

Ita, E. (2018). Manajemen Pembelajaran Pendidikan Anak Usia Dini Di Tk Rutosoro Kecamatan Golewa Kabupaten Ngada Flores Nusa Tenggara Timur. Jurnal Dimensi Pendidikan Dan Pembelajaran, 6(1), 45-52. https://doi.org/10.2426/dpp.v6i1.

Kariyana, I., \& Sonn, R. A. (2012). Teaching Methods and Learners' Concept Formation, Development and Integration in Geometry: Assessing the Relationship. International Journal of Educational Sciences, 1(12), 75-88.

Milles, M. B., \& Huberman, A. M. (1992). Analisis Data Kualitatif. (Cecep Rohindi, Ed.) (UI press). Jakarta.

Mulya, E. (2014). Manajemen PAUD. Bandung: Remaja Rosdakarya.

Mursid. (2015). Belajar dan Pembelajaran PAUD. Bandung: PT. Remaja Rosda Karya.

Nurani S. (2013). Konsep Dasar Pendidikan Anak Usia Dini (7th ed.). Jakarta: Indeks.

Suharni. (2019). Manajemen Pendidikan Anak Usia Dini Pada Paud Bintang Rabbani Pekanbaru, 4(1), 1-5.

Suherman, S., Komarudin, K., Rosyid, A., Aryanita, S., Asriyanto, D., Aradika Putra, T., \& Anggoro, T. (2018). Improving Trigonometry Concept Through STEM (Science, Technology, Engineering, and Mathematics) Learning. SSRN Electronic Journal. https://doi.org/10.2139/ssrn.3248139 